\title{
Philosophy in Review
}

\section{Charles L. Lowery and Patrick M. Jenlink, (Eds.), "The Handlbook of Dewey's Educational Theory and Practice."}

\section{Mark Porrovecchio}

Volume 41, numéro 4, novembre 2021

URI : https://id.erudit.org/iderudit/1084778ar

DOI : https://doi.org/10.7202/1084778ar

Aller au sommaire du numéro

Éditeur(s)

University of Victoria

ISSN

1206-5269 (imprimé)

1920-8936 (numérique)

Découvrir la revue

Citer ce compte rendu

Porrovecchio, M. (2021). Compte rendu de [Charles L. Lowery and Patrick M. Jenlink, (Eds.), "The Handbook of Dewey's Educational Theory and Practice."]. Philosophy in Review, 41(4), 247-249. https://doi.org/10.7202/1084778ar 
Charles L. Lowery and Patrick M. Jenlink, eds. The Handbook of Dewey's Educational Theory and Practice. Brill 2019. 367 pp. \$156.00 USD (Hardcover 9789004405318); \$60.00 USD

(Paperback 9789004405301).

Charles L. Lowery and Patrick M. Jenlink's The Handbook of Dewey's Educational Theory and Practice is, as the promotional material suggests, designed for a readership that is 'interested in the educational work of John Dewey, and anyone concerned with educational leadership and/or educational practice in today's schools.' The Handbook covers a lot of ground, which ends up being both a strength and a weakness.

After a short list of figures and notes on contributors, the primary portion of the book is composed of three parts, with each containing a number of chapters of varying lengths. Each chapter provides useful references at its end, with some also including endnotes that range in detail and length. The body of the book is followed by a very brief subject index. What follows is a series of snapshots from each of the three parts of the book.

'Part One: Dewey and Educational Theory' features eight chapters. In 'Dewey's Social Imaginary of Democratic Education: Democracy's Role in Educating a Democratic Citizenry,' Jenlink provides a useful, if somewhat idealistic, overview of some key tenets of Dewey's pragmatic approach to education. As the chapter title implies, the focus is 'on how people, the public, think about government and being governed, and about social institutions like education and the role of education educating a democratic citizenry' (11). Relying heavily on primary texts from Dewey, as well as the works of Canadian philosopher Charles Taylor, Jenlink works to connect Dewey in conceptualizations to the contemporary realm, urging that 'At this time in American society ... the concern for education in democracy takes on a new sense of urgency' (15). What is lacking, however, is a clear expression of how to tie Dewey's ideas to specific contemporaneous exigencies in education. After some editing stumbles in the first two paragraphs, Peter Nelsen's 'John Dewey and Social Justice Education' offers practical advice for positive changes while also grappling with Dewey's complicated relationship with the idea of race. He highlights how, by contextualizing habits (60) and seeing growth as a method of 'enhancing interdependence' (63), educators might overcome the perniciousness of student-tracking that institutionalizes class and racial divides. Nelson also works to offset some of Dewey's more colonialist tendencies by linking pragmatism to 'American Indian and feminist thought and practice' (64). Barbara J. Thayer-Bacon's 'John Dewey and Feminism' provides a necessary reminder of the complications in Dewey's relationship with female activists and scholars. She notes that his approach both helped and hampered women in his day (75). But then, Thayer-Bacon reintroduces readers to some of Dewey's contemporaries like educators Ella Flagg Young (1845-1918) and Elsie Ripley Clapp (1879-1965), before pointing to his continued inspiration, as found in the works Amy Gutmann, current President of the University of Pennsylvania and nominee to be the United States Ambassador to Germany, and Shannon Sullivan, Chair of the Philosophy Department at the University of North Carolina at Charlotte.

There are seven chapters in 'Part Two: Dewey and Educational Practice.' Alison Taysum's 'A Dewey Framework for Moral Training for Democracy in Education' is an expansive discussion that suffers from some clunky exposition and a couple of puzzling sections. Taysum is to be applauded for arguing for an approach to education which 'celebrates cultural heritages and their intersectionalities with all religions, those of all faiths and none and the social spirit' (148). But, as with Jenlink's essay in the previous section, there is a curious lack of specifics. In less than fifteen pages, Taysum also tries to integrate a dizzying array of thinkers - ranging from Hannah Arendt, to 
Michel Foucault, to John Stuart Mill, to Niccolò Machiavelli-with some only including an in-text citation and no corresponding entry in the list of references. Moreover, her coverage of Aristotle's artistic proofs feels both lightly and confusingly integrated into her discussion of Dewey's theories and is then followed by an unclear citation of Socrates on the next page (144-45). Stephanie A. Burdick-Shepherd's 'Souls in the Lab: Building Rich Practical Experiences for Student Teachers and Young Children' provides, by contrast, a much more grounded approach. Framed as a review/reflection on Dewey's 'Theory and Practice of Education' (1904), the author explores how to create 'a capacity for life-long learning in educators' (176). Burdick-Shepard goes on to critique approaches to training, such as traditional labs and apprenticeships, suggesting that a Deweyan approach would emphasize learning 'to teach the subject or the content of teaching in the way in which one learns it' (181). Burdick-Shepard also provides instructive case studies, one focusing on her experiences observing elementary teaching in Finland and one highlighting the story-telling techniques of kindergarten teacher Julie Diamond (184-185). Laura M. Harrison and Shah Hasan's 'Promoting Educational Equity through Democratizing Intelligence' does useful work in arguing for a different method for assessing students by contextualizing the viewpoints of psychologist Edward Lee Thorndike and Dewey as classical and contemporaneous alternatives. They argue that Thorndike's approach has led to the destructive conflation of intelligence with race and/or class, manifest in the current emphasis on tracking with its 'seemingly fair and objective ability groupings' (207). The Deweyan alternative would instead focus on psychologist Howard Gardner's multiple intelligences; it would highlight 'that different domains of knowledge require and generate different adaptive competencies that contrast with current measures of cognitive talent' (213).

'Part Three: Dewey and the Scholar-Practitioner Educational Leader' concludes with seven chapters. Chetanath Gautam's 'Organic Pedagogy: Where Dewey's Democracy and Foucault's Poststructuralism Meet: Pedagogical Experiences, Applications, and Critique' takes a case study approach to a unique pairing of distinctly different philosophers. Based on experience in a doctoral class, Gautam argues for organic pedagogy, 'where the student and the professors truly blur the boundary of teaching and learning making the learning process a multidimensional phenomenon' (289). The process engages three dimensions: (1) neuroscientific, with an emphasis on using 'varied approaches of analysis and interpretation' (295); sociocultural, which transforms the learning environment into 'a place to share cultural experiences' (297); and symbolic-metaphoric, where creative explanations are celebrated 'as tools to explain experiences' (297). Gautam ends by noting that, as with both Dewey and Foucault, this pedagogical process welcomes the 'opportunity to critique the process itself' (300). Chance D. Mays' 'Experienced, but Not Yet Educated: How Dewey Should Still Contribute to Educational Philosophy' works as a personal reflection paper based on how Dewey's Experience and Education (1938) led him to revise his own philosophy of education. The central revelation for Mays was the transactional nature of Dewey's approach to experience (306). But a transformative approach to teaching, one that sees the 'students as individuals' (310), is complicated. So much more the pity that Mays doesn't sketch out practical changes he made in his teaching. Monica Hatfield Price's 'How the Dewey-Lippmann Debate Informs Contemporary Education Policy' centers on critiquing how Lippmann's ideas still hold sway. Price notes the current pervasiveness of both think tanks and outmoded ideas about the public's capacity for a participatory role in democracy. The former enshrines an 'elitist model of democracy in the contemporary education policy arena' (335). The latter defines college education as merely a means for job preparation, suggesting that 'civic education for the masses would be futile' (339). Price pushes for a Deweyan counter, one with faith in a more democratic and 'dispersed public power' (342). As with Mays, though, what form that pushback would take is largely left implicit. 
There are, as intimated in the discussion above, some gentle criticisms that can be raised about The Handbook. As noted, the subject index is very short. It would have benefited from more entries, and perhaps the addition of an author index as well. A larger set of issues relate back to the targeted readership for the book. Absent a framing device, such as an introductory chapter from the editors or section overviews, readers are left to jump in with only the section titles providing an organizational roadmap. A more philosophical quibble relates to the first two sections. Given that pragmatism is known for its emphasis on application, having distinct sections devoted to theory and practice can be problematic, as there will be bleed-through in coverage and points of emphasis. As a result, it isn't always clear that a specific chapter belongs in a specific section. While it is clear that those interested in Dewey are the primary audience, the secondary claim that it will engage those interested in 'educational leadership and/or educational practice in today's schools' remains largely an implication of the discussions in the third part of the book, and not a matter of specifics relating to either leadership or best practices. It is also more generally the case that, with twenty-two chapters, by a range of authors with various backgrounds, the overall quality of the writing varies.

Jenlink and Lowery's Handbook is a wide-ranging addition to the already crowded Dewey canon. Even readers already well-versed in Deweyan theory are likely to find a chapter or two that provides a unique and engaging discussion. As is common, The Handbook is to be recommended for some of its parts and not necessarily the whole.

Mark Porrovecchio, Oregon State University 